\title{
1.94-1.93 Ga charnockitic magmatism from the central part of the Guyana Shield, Roraima, Brazil: Single-zircon evaporation data and tectonic implications
}

\author{
Lêda Maria Fraga ${ }^{\mathrm{a}, *}$, Moacir Jose Buenano Macambira ${ }^{\mathrm{b}}$, Roberto Dall'Agnol ${ }^{\mathrm{b}}$, João Batista Sena Costa ${ }^{\mathrm{b}}$ \\ ${ }^{a}$ CPRM - Geological Survey of Brazil, Department of Geology, Av. Pasteur, 404, 22290-240 Rio de Janeiro, Rio de Janeiro, Brazil \\ b Isotope Geology Laboratory, Center of Geosciences, Federal University of Pará, Rua Augusto Corrêa s/n, Guamá 66075-110, Belém, Pará, Brazil
}

\section{A R T I C L E I N F O}

\section{Article history:}

Received 27 November 2007

Accepted 12 February 2009

\section{Keywords:}

Geochronology

Charnockitic magmatism

Paleoproterozoic

Guyana shield

Amazonian craton

\begin{abstract}
A B S T R A C T
Age and origin of the charnockitic rocks of the central part of the Guyana Shield have been a matter of discussion. These rocks have been interpreted either as Transamazonian granulites metamorphosed around $2.02 \mathrm{Ga}$ or as $1.56 \mathrm{Ga}$ old igneous charnockites. Recently, most of the Roraima charnockitic rocks have been recognized as igneous rocks and included into the Serra da Prata Suite (SPS). Five Pb-Pb singlezircon evaporation ages were obtained for samples representative of different facies of the SPS and these constrained the age of the charnockitic magmatism between $1943 \pm 5 \mathrm{Ma}$ and $1933 \pm 2 \mathrm{Ma}$. This charnockitic magmatism may be related to a post-collisional setting after the evolution of the CauaraneCoeroeni Belt $(\sim 2.00 \mathrm{Ga}$ ), or may represent a post-collisional (or intracontinental?) magmatism related to orogenic activities along the plate margins around $1.95-1.94 \mathrm{Ga}$.
\end{abstract}

(c) 2009 Elsevier Ltd. All rights reserved.

\section{Introduction}

The Guyana Shield constitutes the northern part of the Amazonian craton, a large tectonic unit situated in northern South America (Almeida and Hasui, 1984) (Fig. 1, inset). The craton is limited to the west by the Phanerozoic Andean Belt and to the east and southeast by Neoproterozoic orogenic belts. Elongated bodies of charnockitic rocks were identified in the central portion of the shield, in Guyana and in Roraima, Brazil (Fig. 1). Age and origin of these charnockitic bodies remain poorly studied.

In Guyana, charnockitic rocks showing magmatic texture were considered part of the Kanuku Complex, which is mainly formed of migmatitic supracrustal rocks, mafic and felsic granulites and augen gneisses (Berrangé, 1977). The only available geochronological data for the charnockites of the Kanuku Complex are $\mathrm{Rb}-\mathrm{Sr}$ whole-rock isochronic ages in the 2.02-2.18 Ga interval (Spooner et al., 1971). Besides the limitations of the method itself, the mentioned $\mathrm{Rb}-\mathrm{Sr}$ ages were calculated using rocks of different petrological origin and are therefore not reliable.

The charnockitic rocks of central-east Roraima, Brazil, have also been traditionally related to the Kanuku Complex (e.g. Santos and Olszewski, 1988; Gaudette et al., 1996). A Rb-Sr errorchron of 2019 Ma was assumed to "reflect the time of the high grade metamorphism" of the complex, and a $1827 \pm 19 \mathrm{Ma} \mathrm{U}-\mathrm{Pb}$ conventional age has been reported for a charno-enderbite interpreted as a granulite (Table 1; Gaudette et al., 1996). Most of the charnockitic

\footnotetext{
* Corresponding author. Tel.: +55 21 25429793; fax: +55 2122954992.

E-mail address: ledamari@rj.cprm.gov.br (L.M. Fraga).
}

bodies previously considered as granulites and related to the Kanuku Complex have been recognized as igneous rocks and included in the Serra da Prata Suite (Fraga et al., 1997b; Fraga and Araújo, 1999). Based on a $1564 \pm 21 \mathrm{Ma}$ age obtained for an igneous-looking quartz mangerite (sample $\mathrm{NN}-234, \mathrm{~Pb}-\mathrm{Pb}$ zircon evaporation, Fraga et al., 1997a; Fig. 2, Table 1), the suite has been interpreted as Mesoproterozoic and admitted as closely related to the Mucajaí rapakivi granite. Subsequent studies have identified a mangerite facies in the Mucajaí Granite batholith close to the contact with the Repartimento massive-type anorthosite, and an anorthositemangerite-rapakivi granite (AMG) complex was defined (Fig. 2; Fraga, 2002). The $\mathrm{Pb}-\mathrm{Pb}$ zircon evaporation age of $1538 \pm 5 \mathrm{Ma}$ (Fraga, 2002; Fig. 2, Table 1) obtained for the mangerite facies of the AMG complex is close to the value reported for the quartz mangerite (sample NN-R234), interpreted as related to the SPS. However, when compared to the mangerites of the Mucajaí AMG complex, the charnockitic rocks of the SPS show marked chemical and microstructural differences (Fraga, 2002). This observation throws doubt upon the close genetic link between the SPS and the Mesoproterozoic Mucajaí AMG complex assumed by Fraga et al. (1997a).

Other available geochronological dating for charnockitic rocks in the central-eastern part of Roraima corresponds to the 1966 $\pm 37 \mathrm{Ma}$ age ( $\mathrm{Pb}-\mathrm{Pb}$ zircon evaporation age; Fraga et al., 1997a; Table 1) calculated for a quartz jotunitic gneiss with preserved relicts of igneous texture. The dated quartz jotunitic body shows conspicuous chemical differences when compared with the SPS rocks and has been related to the Rio Urubu Suite (Fraga et al., 1999). Finally, a $1938 \pm 12$ Ma age (U-Pb zircon, SHRIMP, Santos, 2003; Table 1) 


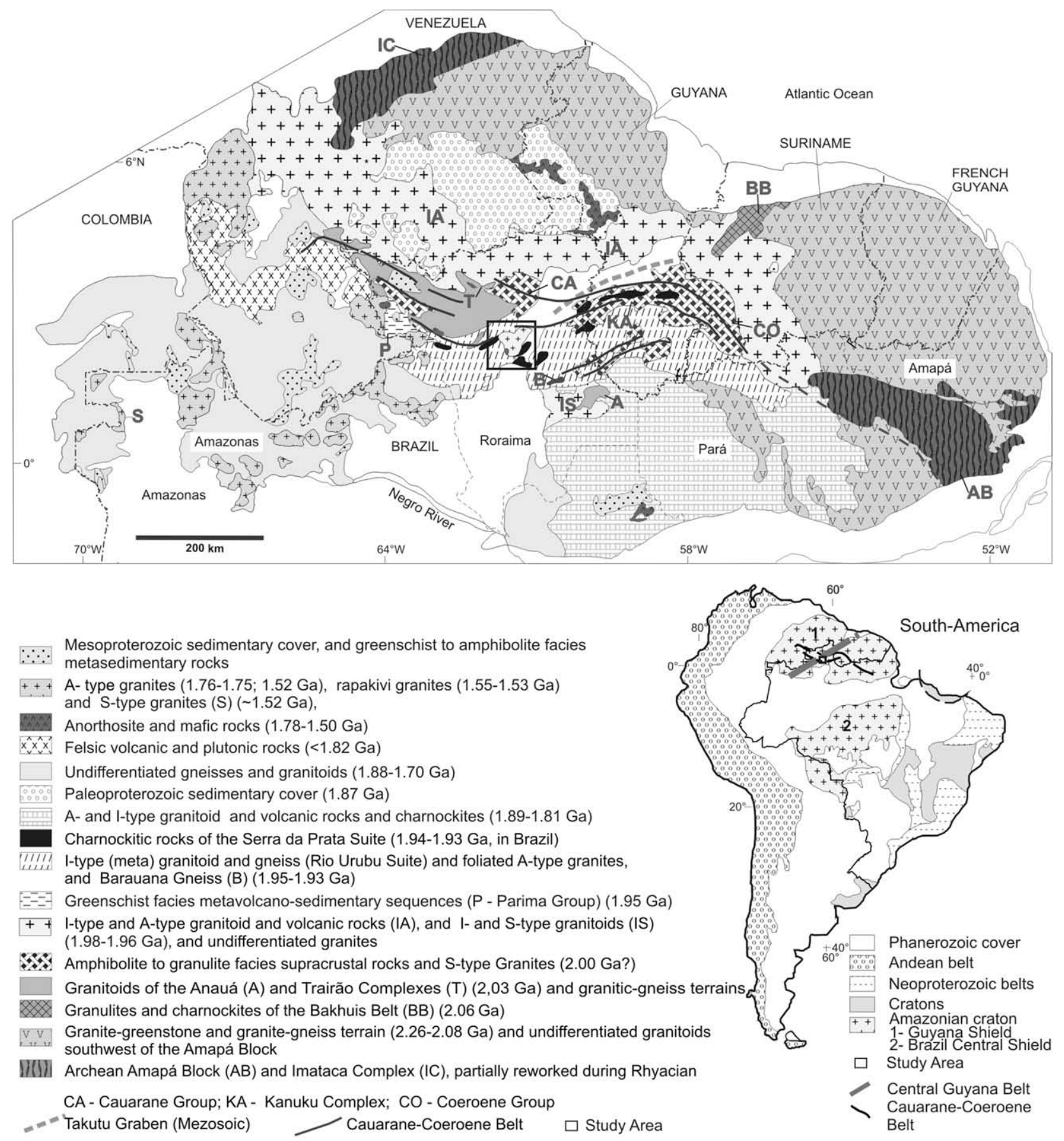

Fig. 1. Geological sketch map of the Guyana Shield and the location of the study area (condensed and modified from Berrangé (1977), Kroonemberg (1976), Wynn et al. (1983), De Vleter et al. (1998), Cole and Heesterman (2002), Fraga (2002), Delor et al. (2003a), Schobbenhaus et al. (2004), Tapias et al. (2006), Rosa-Costa et al. (2006)). The position of the Amazonian craton with respect to the main tectonic elements of South America (modified from Almeida and Hasui (1984)) is also shown.

has been reported for the hypersthene-bearing granulitic Barauana Gneiss (Faria et al., 2000) (Fig. 1).

The geochronological data available for the charnockitic rocks exposed in the central portion of the Guyana Shield (Table 1), briefly discussed above, point out the important inconsistencies in regard to age and origin of these rocks. The Serra da Prata region, in the central part of Roraima, is a key area for the characterization of the nature and age of the charnockitic rocks. This paper presents field and petrographic data as well as five new $\mathrm{Pb}-\mathrm{Pb}$ evaporation zircon ages for the SPS, constraining the age of this important charnockitic magmatism, which took place in a time interval of ca. $10 \mathrm{Ma}$, between $1933 \pm 2 \mathrm{Ma}$ and $1943 \pm 5 \mathrm{Ma}$. The results are dis- cussed in the context of an updated overview of the geology of the Guyana Shield aiming to contribute to a better understanding of the regional geological evolution.

\section{Regional geology}

The Guyana Shield constitutes one of the less studied Precambrian areas in the world and the general geological knowledge of the region remains at reconnaissance scale.

Concerning the central and southwestern part of the shield, it has been traditionally accepted that the NE-SW Central Guyana Belt (CGB) (Fig. 1, inset), extending from Surinam to the northern 

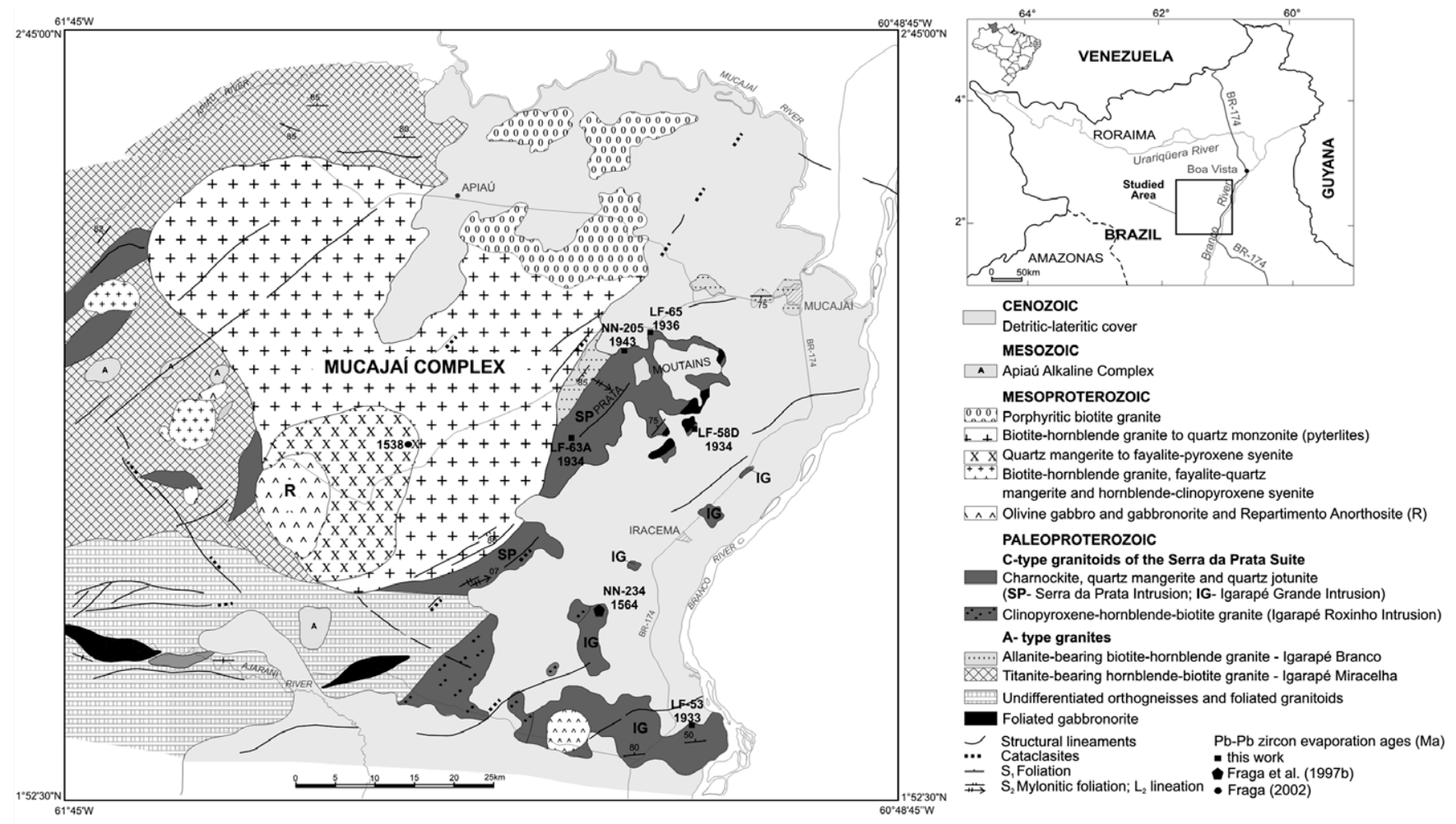

Fig. 2. Geological sketch map of the study area.

part of the Amazonas State, Brazil, corresponds to a major Paleoproterozoic tectonic feature (Gibbs and Barron, 1993; Lima et al., 1982; Costa et al., 1991; Fraga et al., 1998; Reis et al., 2003). However, as pointed out by Fraga (2002) the CGB is not a coherent structure. The basement rocks, as well as the high-temperature foliations that define this structural feature along its northeastern, central and southwestern part, were developed during different periods of the Paleoproterozoic evolution of the shield. New geological mapping allied to pioneering work on the Guyana Shield (Barron, 1966; Berrangé, 1977; Kroonemberg, 1976) has led to the recognition that the main Paleoproterozoic tectonic feature of the central part of the shield corresponds to the Cauarane-Coeroni Belt, a sinuous NW-SE/NE-SW/NW-SE structure, including amphibolite to granulite facies supracrustal rocks of the Cauarane Group in Brazil, Kanuku Complex in Guyana and Coeroeni Group in Surinam (Fig. 1) (Fraga et al., 2008a). This sinuous belt Coeroeni has been previously mentioned by Kroonemberg (1976), Fraga (2002), and Delor et al. (2003b). The belt divides the Guyana Shield into two domains (Fraga et al., 2008a) (Fig. 1). The northern domain encompasses preserved juvenile Rhyacian 2.08-2.22 Ga old granite-greenstone terrains, mainly formed in island arc tectonic settings (Vanderhaege et al., 1998; Delor et al., 2003a), and Archean blocks (Amapá Block, Rosa-Costa et al., 2006; and Imataca Complex, with Archean relicts, Tassinari et al., 2004). Rhyacian terrains partially recycled at around $2.06 \mathrm{Ga}$ (Bakhuis belt, Delor et al., 2003b; Roever et al. 2003) also occur in the northern domain. In a contrasting scenario, in the southern domain, basement consists of rock units younger than $1.88 \mathrm{Ga}$ (southwestern part of the shield, Gaudette and Olszewski 1985; Santos et al., 2000) or has been significantly obliterated by extensive felsic plutonism and volcanism in the 1.89-1.81 Ga interval during the Uatumã Event (south-central part of the shield, Reis et al., 2003). Fragments of a $2.03 \mathrm{Ga}$ old crust, corresponding to dominantly low-K calc-alkaline quartz diorites, tonalites and granodiorites of the Anauá (Faria et al., 2002) and Trairão (Fraga et al., 2008b) complexes, have recently been identified close to the Cauarane-Coeroeni Belt and have been interpreted as remnants of magmatic arcs. These $2.03 \mathrm{Ga}$ terrains extend to the west, probably forming the basement of the northwestern portion of Roraima. According to Fraga et al. (2008a,b), the main tectono-thermal event along the Cauarane-Coeroeni Belt occurred at around $2.00 \mathrm{Ga}$, recording the collision of the Anauá and Trairão arcs with the juvenile Rhyacian crustal masses. A post-collisional A-type and high-K calc-alkaline I-type volcano-plutonic magmatism (Fraga et al., 1997c; Fraga et al., 2008c), extends along the northern border of the CauraneCoeroeni Belt. In Roraima, Brazil, ages of 1.98-1.96 Ga have been reported for this volcano-plutonic magmatism (U-Pb SHRIMP, Santos, 2003; Schobbenhaus et al., 1994). I- and S-type granitoids with

Table 1

Available ages for the charnockitic rocks from central Roraima.

\begin{tabular}{|c|c|c|c|}
\hline Lithology & Methodology & Age (Ma) & References \\
\hline Enderbite/charno-enderbite/piro-xenite/granite-gneiss (Kanuku Complex) & $\mathrm{Rb}-\mathrm{Sr}$ whole-rock errorchron & $2019 \pm 71$ & Gaudette et al. (1996) \\
\hline Charnoenderbite (Kanuku Complex) & $\mathrm{U}-\mathrm{Pb}$ - zircon & $1827 \pm 19$ & Gaudette et al. (1996) \\
\hline Quartz jotunitic gneiss (Rio Urubu Suite) & $\mathrm{Pb}-\mathrm{Pb}$ evaporation - zircon & $1966 \pm 37$ & Fraga et al. (1997a) \\
\hline Quartz mangerite (?) & $\mathrm{Pb}-\mathrm{Pb}$ evaporation - zircon & $1564 \pm 21$ & Fraga et al. (1997a) \\
\hline Quartz mangerite (Mucajaí AMG Complex) & $\mathrm{Pb}-\mathrm{Pb}$ evaporation - zircon & $1538 \pm 5$ & Fraga (2002) \\
\hline Granulite (Barauana Gneiss) & U-Pb SHRIMP - zircon & $1938 \pm 12$ & Santos (2003) \\
\hline
\end{tabular}




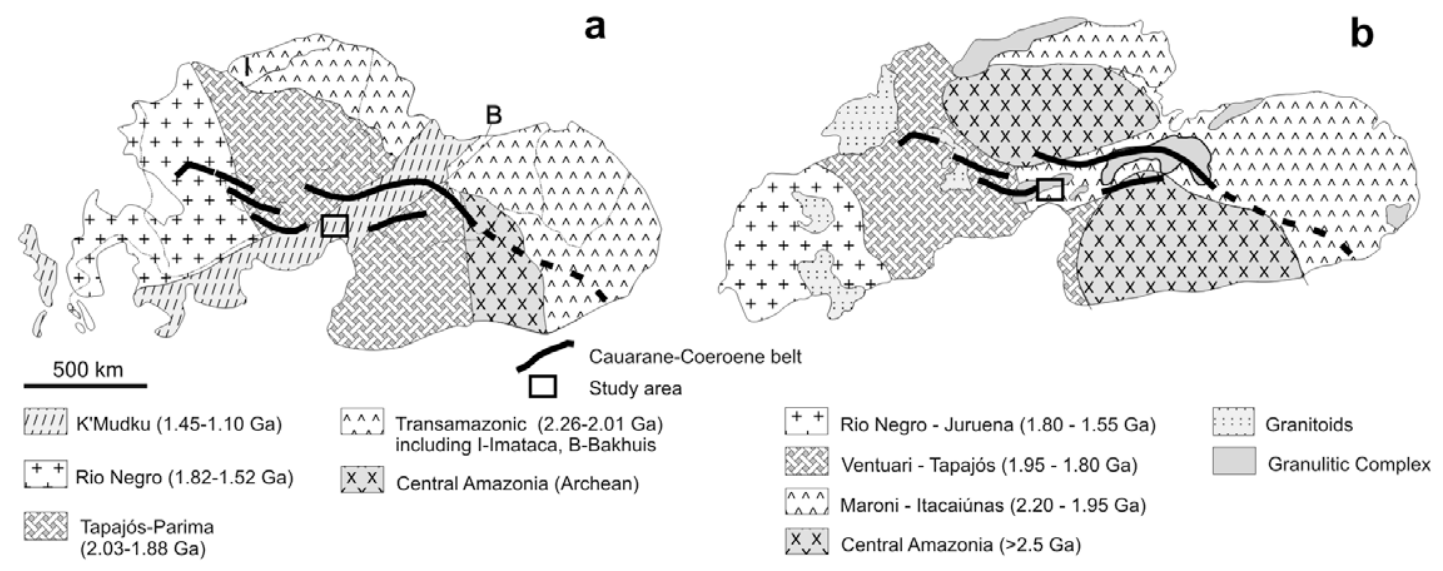

Fig. 3. Geochronological provinces for the Guyana Shield: (a) Santos et al. (2000, 2006); (b) Tassinari and Macambira (2004).

ages in the 1.98-1.96 Ga interval have also been identified in the southern domain (Fig. 1) and were interpreted as products of collisional magmatism (Almeida et al., 2007). Moreover, south of the Caurane-Coeroeni Belt, in Roraima, calc-alkaline, I-type rocks of the Rio Urubu Suite (Fraga et al. 1999) and foliated A-type granites have been identified. The SPS occurs associated with these rock types, and its distribution is controlled by the Cauarane-Coeroeni Belt (Fig. 1). The Rio Urubu Suite is mainly formed of (meta) granitoid rocks with variably developed foliation, occasionally parallel to a magmatic foliation, and gneisses deformed under amphibolite facies conditions. The suite, with ages of $1.95 \mathrm{Ga}$ to $1.91 \mathrm{Ga}(\mathrm{U}-\mathrm{Pb}$ SHRIMP and conventional ages; Gaudette et al., 1996; Santos, 2003), correlates with the Southern Guyana Complex (Berrangé, 1977 ) in Guyana. The foliated A-type granites present ages in the 1.94-1.93 Ga interval (Pb-Pb and U-Pb SHRIMP, Fraga, 2002; Santos, 2003) and have been interpreted as syn-kinematically emplaced in a transpressional, post-collisional setting (Fraga, 2002; Fraga et al., 2006). An isolated lens of the granulitic, polyfolded, compositionally banded, intermediate to basic Barauana gneiss also occurs south of the Cauarane-Coeroeni Belt (Fig. 1). It is worth noting the contrasting structural pattern between the Barauana Gneisses interpreted as a mega-enclave (Faria et al., 2000) and the enclosing Rio Urubu Suite in which evidences of polyphase evolution, and of granulite facies metamorphism, are lacking. A $1.94 \mathrm{Ga}$ age was reported for the Barauana Gneiss (Santos, 2003). Greenschist facies metasedimentary and metavolcanic rocks of the Parima Group, dated at $1.95 \mathrm{Ga}$ (age of a metandesite) with maximum deposition age around $1.97 \mathrm{Ga}$ (U-Pb SHRIMP on zircon, Santos et al., 2003b), crop out in the northwestern part of Roraima. Paleoproterozoic intracratonic sedimentary sequences (Roraima Supergroup, $1.87 \mathrm{Ga}$, U-Pb SHRIMP on zircon, Santos et al., 2003a) cover large areas of the central-north portion of the shield and Mesoproterozoic sedimentary sequences occur to southwest. During the Mesoproterozoic, numerous batholiths and stocks of rapakivi granites and associated mafic rocks intruded the Paleoproterozoic basement of the central and western part of the shield. Narrow and localized, mylonite-pseudotachylite belts (not represented in Fig. 1) were developed during the K'Mudku Event $(1.2 \mathrm{Ga})$, reactivating previous high-temperature structures.

Considering the geochronological province models proposed for the Amazonian craton (Fig. 3), the central portion of the Guyana Shield was divided in the Central Amazonia (>2.5 Ga), Maroni-Itacaiúnas (2.20-1.95 Ga), and Ventuari-Tapajós provinces (1.95$1.80 \mathrm{Ga}$ ) (Tassinari and Macambira, 2004), or was related to the Central Amazonia (supposedly Archean), Transamazonic (2.26$2.01 \mathrm{Ga})$, Tapajós-Parima (2.03-1.88 Ga) and K'Mudku (1.45$1.10 \mathrm{Ga}$ ) provinces (Santos et al., 2000; Santos et al., 2006). Despite the relevant contribution of the geochronological province models to the understanding of the geological evolution of the Amazonian craton, the recognition of a new tectonic framework for the central Guyana Shield, with the definition of the Caurane-Coeroeni Belt, imposes a re-evaluation of these models.

\section{Geology of the study area}

In the study area, situated in the central part of Roraima, Brazil, the Serra da Prata Suite is closely associated with foliated A-type granites and mafic rocks (Fig. 2). Two groups of A-type granites were distinguished: the Igarapé Branco Granite (IBG), containing hornblende, biotite and allanite as principal mafic minerals, and the Igarapé Miracelha Granite (IMG), with biotite, hornblende and titanite. The mafic rocks occur as small bodies of foliated gabbronorite and, inside the IBG, IMG and SPS, as enclaves showing dropped alkali feldspar crystals, indicating the coexistence of mafic and felsic magmas. The SPS consists of three major NE-SW elongated intrusions, named Serra da Prata, Igarapé Grande and Igarapé Roxinho, which are partially overlain by Cenozoic sedimentary cover, and includes some minor bodies, identified in the western part of the area (Fig. 2). The IBG and IMG, the charnockites of the SPS and the gabbronorites are the host rocks of the Mesoproterozoic Mucajaí Anorthosite-Mangerite-Rapakivi Granite (AMG) Complex (Fraga, 2002; Fraga et al., 2003) (Fig. 2). The complex is asymmetrically zoned and the mangerites crop out between the anorthosite body and the main pyterlitic facies. The host rocks and the Mesoproterozoic AMG Complex exhibit different structural patterns. A NE-SW mylonitic foliation $\left(\mathrm{S}_{2}\right.$, Fig. 2$)$, defined by low temperature deformational fabrics, occurs close to the southeastern contact of the Mucajaí rapakivi granite with the IBG and SPS, and is related to the $\sim 1.2 \mathrm{Ga} \mathrm{K}^{\prime} M u d k u$ Episode. The IBG, IMG and SPS display variably developed E-W to NE-SW trending foliations $\left(S_{1}\right.$, Fig. 2$)$, characterized by high-temperature subsolidus deformational fabrics which are not imprinted in the AMG Complex. In the SPS isotropic, igneous-looking rocks predominate (Fig. 4a-e) over foliated types. The high-temperature solid state deformation fabrics observed in the IBG, IMG and SPS are also recorded in syn-plutonic dykes. These dykes are co-magmatic with the IBG and IMG, and crosscut early-kinematic structural features in both units. The observations indicate that the deformation took place during the emplacement and crystallization of the studied rocks. When part of the granite bodies had already crystallized and undergone solid state deformation, there was still some melt left in the magmatic chamber that was then emplaced as dykes crosscutting early-kinematic structural features in the granites (Fraga, 2002; Fraga and Costa, 2003). During the ongoing process of syn-kine- 

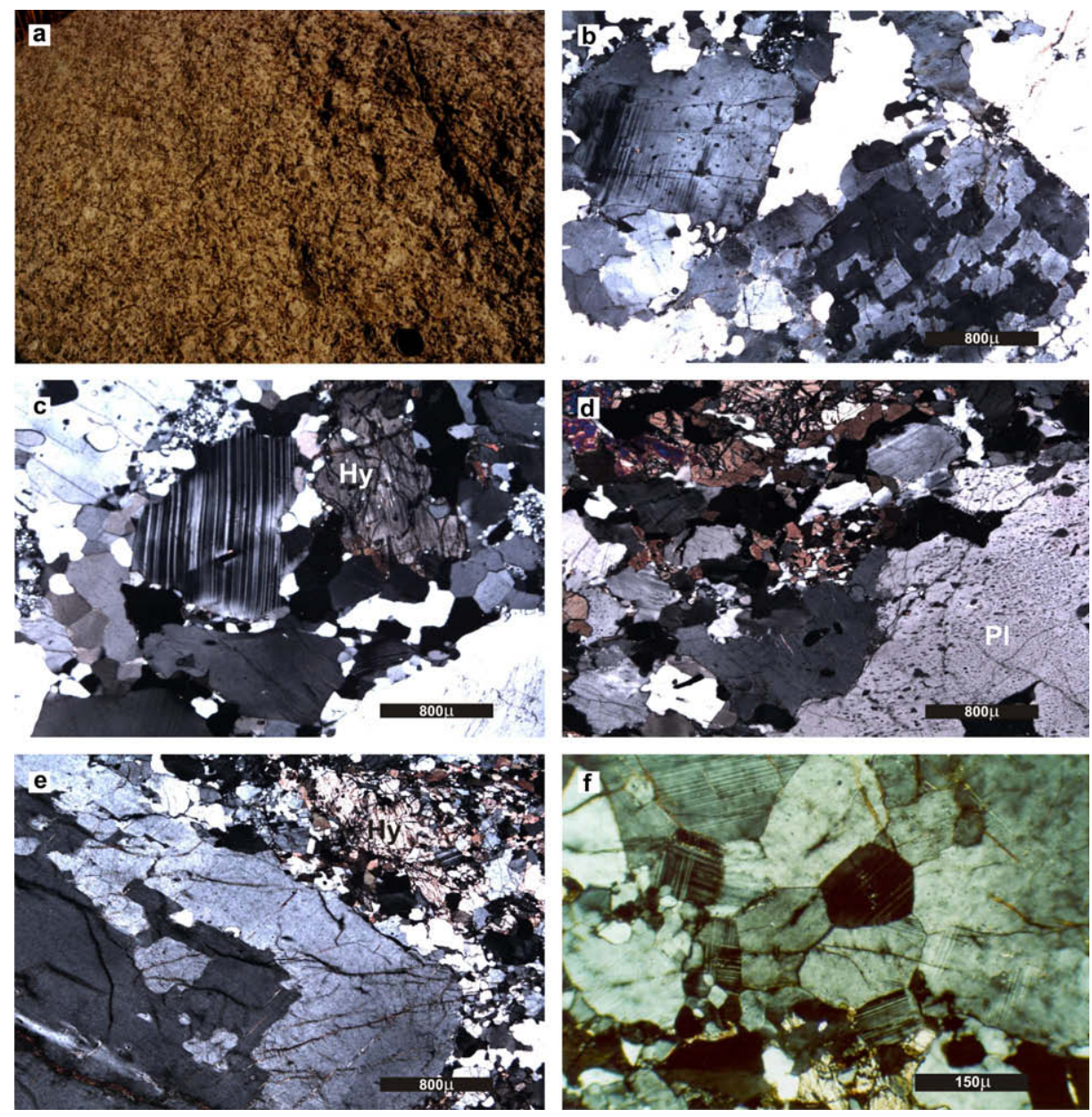

Fig. 4. Meso- and microscopic aspects of the SPS: (a) Coarse-grained isotropic hypersthene-quartz syenite, sample LF-63A, Serra da Prata intrusion; (b) Hypidiomorphicgranular texture in charnockite. Sample LF-46, Igarapé Grande intrusion. X-polars; (c) Hypidiomorphic-granular charnockite with recrystallized quartz at bottom left and hypersthene crystal (Hy) at top right. Sample LF-10C, Igarapé Grande intrusion. X-polars; (d) Antiperthitic plagioclase (Pl) in charnockite. Clinopyroxene) and hypersthene at top left. Sample LF-62, Serra da Prata intrusion. X-polars; (e) Rapakivi texture in charnockite. Hypersthene crystal (Hy) at top right. Sample LF-41, Igarapé Grande intrusion. Xpolars; (f) Partially recrystallized plagioclase in charnockite. Sample LF-41, Igarapé Grande intrusion. X-polars.

matic emplacement, the dykes were deformed under high-temperature conditions. A transpressional setting has been proposed for the emplacement of the IBG, IMG and SPS (Fraga, 2002).

The IBG and IMG were dated at $1937 \pm 5 \mathrm{Ga}$ and $1935 \pm 5 \mathrm{Ga}$, respectively $\left(\mathrm{Pb}-\mathrm{Pb}\right.$ zircon ages, Fraga, 2002). $\mathrm{Nd} \mathrm{T}_{\mathrm{DM}}$ model ages obtained for both the A-type granites and the charnockites of the SPS are in the range of 2.19-2.05 Ga, with $\epsilon_{\mathrm{Nd}}$ values varying from +0.67 to +2.46 (Fraga et al., 2004). Allied to the petrological characterization of the rock units, the Nd isotopic data suggest a late-Rhyacian, Transamazonian juvenile crustal source for the IBG, IMG and SPS (Fraga et al., 2004).

\section{Petrography}

In the SPS, charnockites predominate and charno-enderbites, quartz mangerites, quartz jotunites and hypersthene syenites are subordinate. The rocks are grey to brownish or greenish grey, medium- to coarse-grained with subordinate fine-grained types. The igneous textures of the charnockitic rocks are usually very well-preserved, despite the common presence of solid state deformational fabrics interpreted as related to the deformation during the emplacement of the charnockitic bodies. Textures vary from hypidiomorphic to allotriomorphic granular or inequigranular (Fig. 4b and c). Porphyritic rocks with euhedral to anhedral feldspar megacrysts are common. The mineral assemblage includes alkali feldspar + quartz + plagioclase + orthopyroxene \pm (clinopyroxene) \pm hornblende \pm biotite. Typical accessory minerals are zircon, opaque minerals (ilmenite and magnetite), apatite (mostly acicular) and rare allanite. The three major intrusions exhibit more than one petrographic facies. In the Serra da Prata intrusion, medium- to coarse-grained charnockites (Fig. 4a) dominate over porphyritic clinopyroxene charnockites with medium- to fine-grained matrix. Antiperthitic plagioclase (Fig. 4d) is characteristic and rapakivi and antirapakivi textures are locally observed. In the northwestern border of the Serra da Prata intrusion, the rocks were deformed, and the pyroxenes were replaced by a hydrated mafic assemblage including amphiboles and biotite. In the Igarapé Grande intrusion, the main facies consists of medium- to coarse-grained charnockites with subordinate clinopyroxene granites and hornblende biotite granites. A fine- to medium-grained quartz jotunite, identified in the southern portion of the intrusion, was interpreted as a dyke. Plagioclase is not antiperthitic in the Igarapé Grande intrusion and rapakivi (Fig. 4e) as well as antirapakivi textures occur. The Igarapé Roxinho intrusion consists of (clinopyroxene)-(hornblende)-biotite granites, corresponding to the only body in which orthopyroxene has not been identified so far. Despite the absence of orthopyroxene, these granites were included in the SPS on the basis of petrographic and chemical similarities with the other intrusions related to the suite. 
Table 2

$\mathrm{New} \mathrm{Pb}-\mathrm{Pb}$ ages for Serra da Prata Suite samples.

\begin{tabular}{lll}
\hline Sample & Lithology/intrusion $^{\mathrm{a}}$ & Coordinates \\
\hline LF-63A & Hypersthene-quartz syenite/SP & $02^{\circ} 16^{\prime} 37.20^{\prime \prime} \mathrm{N} ; 61^{\circ} 11^{\prime} 48^{\prime \prime} \mathrm{W}$ \\
LF-58D & Porphytitic clinopyroxene charnockite/SP & $02^{\circ} 17^{\prime} 06.70^{\prime \prime} \mathrm{N} ; 61^{\circ} 02^{\prime} 40.88^{\prime \prime} \mathrm{W}$ \\
LF-65A & Porphyritic clinopyroxene charnockite/SP & $02^{\circ} 23^{\prime} 51.12^{\prime \prime} \mathrm{N} ; 61^{\circ} 05^{\prime} 24.78^{\prime \prime} \mathrm{W}$ \\
NN-205 & Biotite-hornblende charnockite/SP & $02^{\circ} 22^{\prime} 01.88^{\prime \prime} \mathrm{N} ; 61^{\circ} 07^{\prime} 28.45^{\prime \prime} \mathrm{W}$ \\
LF-53 & Quartz jotunite/IG & $01^{\circ} 57^{\prime} 33.80^{\prime \prime} \mathrm{N} ; 61^{\circ} 02^{\prime} 42^{\prime \prime} \mathrm{W}$ \\
\hline
\end{tabular}

a SP - Serra da Prata intrusion; IG - Igarapé Grande intrusion.

In rocks recording higher strain, the igneous texture was partially obliterated by deformational features, developed under temperatures of about $650-750{ }^{\circ} \mathrm{C}$. Strain variation can be very large, even in the thin-section scale (Fig. 4e and f). Microstructures in alkali feld-
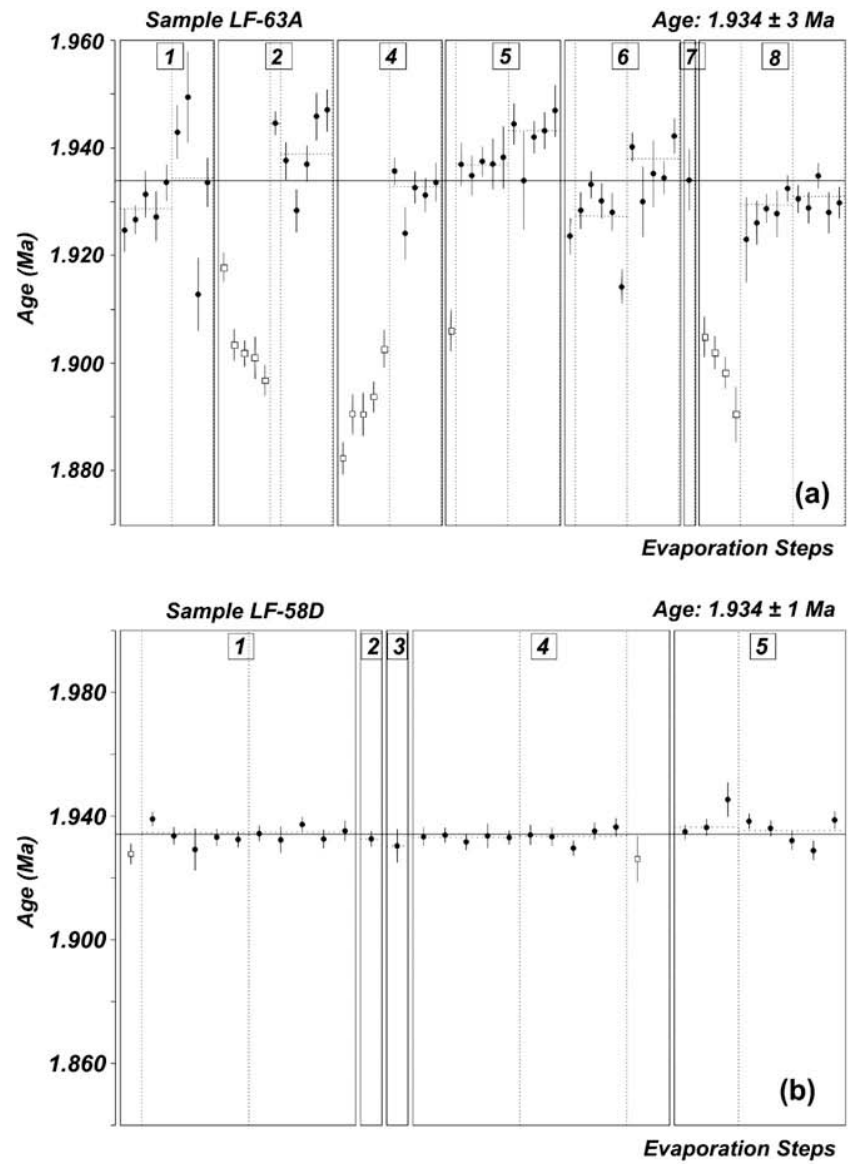

spar and plagioclase grains (Fig. 4f) record recrystallization by the subgrain rotation mechanism (Yund and Tullis, 1991; Passchier and Trouw, 1996). Moreover, the presence of albite exsolution lamellae in recrystallized alkali feldspar records recrystallization
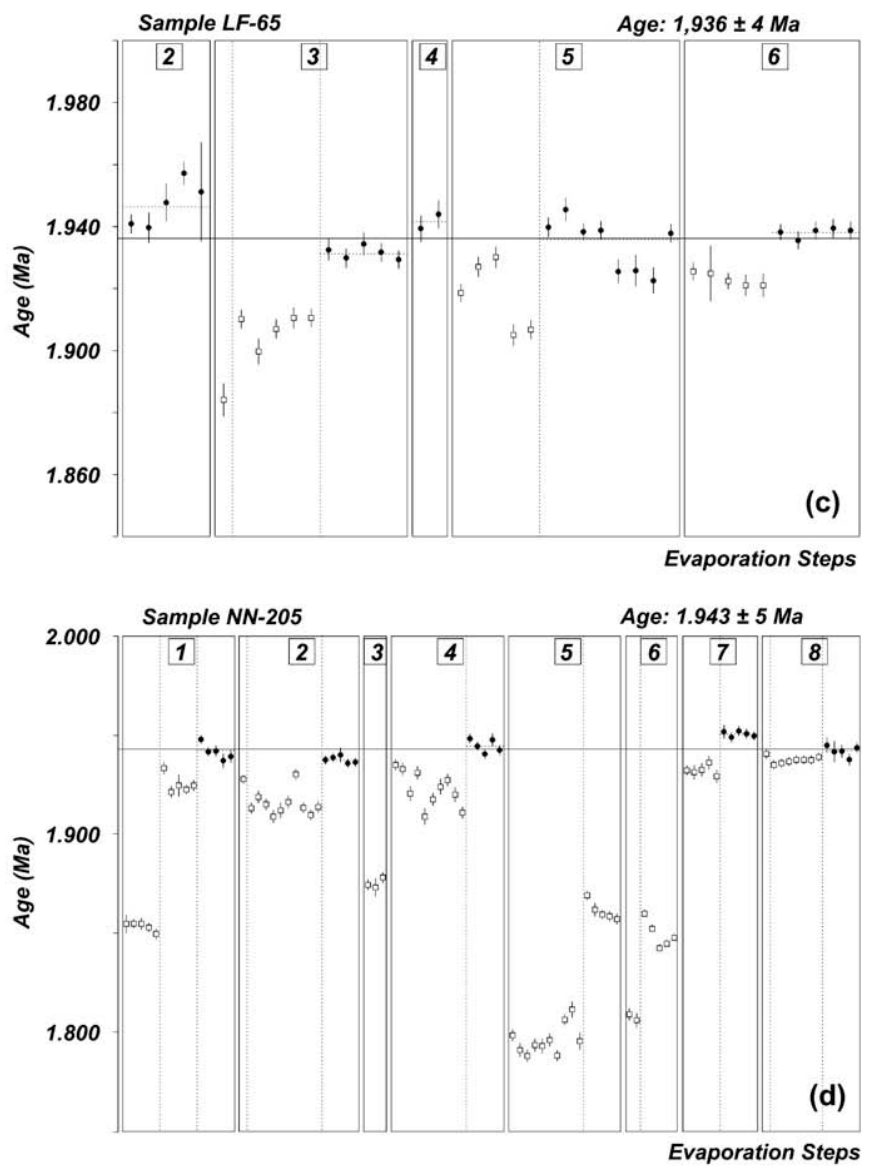

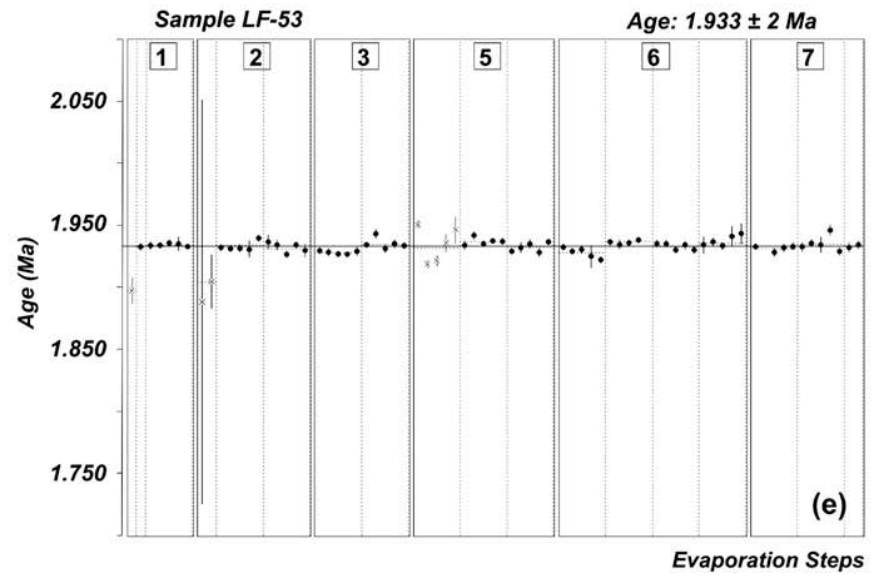

Fig. 5. Age versus evaporation step diagrams for the zircon crystals from samples: (a) LF-63A; (b) LF-58D; (c) LF-65; (d) NN-205; (e) LF-53. Filled Circle - accepted blocks for the age calculation; Square - block subjectively rejected; $\mathrm{X}$ - blocks rejected for showing ${ }^{204} \mathrm{~Pb} /{ }^{206} \mathrm{~Pb}$ ratio higher than 0.0004 . Standard deviation at $2 \sigma$. 
Table 3

Analytical results for the analyzed zircon crystals. c - Pb-Pb ratios corrected for common $\mathrm{Pb}$; $(*)$ - blocks discarded due to their higher or lower values of the ${ }^{207} \mathrm{~Pb} /{ }^{206} \mathrm{~Pb}$ ratio in relation to the mean; (\#) - rejected blocks due to ${ }^{204} \mathrm{~Pb} /{ }^{206} \mathrm{~Pb}>0.0004$. Standard deviation at $2 \sigma$.

\begin{tabular}{|c|c|c|c|c|c|c|c|}
\hline Zircon & Evaporation temperature $\left({ }^{\circ} \mathrm{C}\right)$ & Used/total ratio number & ${ }^{204} \mathrm{~Pb} /{ }^{206} \mathrm{~Pb} \pm 2 \sigma$ & ${ }^{208} \mathrm{~Pb} /{ }^{206} \mathrm{~Pb} \pm 2 \sigma$ & ${ }^{207} \mathrm{~Pb} /{ }^{206} \mathrm{~Pb} \pm 2 \sigma$ & $\left({ }^{207} \mathrm{~Pb} /{ }^{206} \mathrm{~Pb}\right)_{\mathrm{c}} \pm 2 \sigma$ & Age (Ma) $\pm 2 \sigma$ \\
\hline \multirow[t]{2}{*}{ LF-63A/1 } & 1500 & $90 / 90$ & $0.000007 \pm 4$ & $0.12419 \pm 71$ & $0.11823 \pm 21$ & $0.11815 \pm 22$ & $1929 \pm 3$ \\
\hline & 1550 & $72 / 72$ & $0.000019 \pm 17$ & $0.14036 \pm 67$ & $0.11868 \pm 94$ & $0.11854 \pm 87$ & $1934 \pm 13$ \\
\hline \multirow[t]{3}{*}{ LF-63A/2 } & $1450^{*}$ & $0 / 84$ & $0.000077 \pm 7$ & $0.12110 \pm 325$ & $0.11764 \pm 44$ & $0.11658 \pm 49$ & $1905 \pm 7$ \\
\hline & 1500 & $12 / 18$ & $0.000003 \pm 2$ & $0.16288 \pm 86$ & $0.11924 \pm 30$ & $0.11919 \pm 30$ & $1945 \pm 4$ \\
\hline & 1500 & $48 / 48$ & $0.000004 \pm 1$ & $0.15993 \pm 47$ & $0.11887 \pm 42$ & $0.11882 \pm 42$ & $1939 \pm 6$ \\
\hline \multirow[t]{2}{*}{ LF-63A/4 } & $1450^{*}$ & $0 / 50$ & $0.000044 \pm 2$ & $0.11932 \pm 46$ & $0.11632 \pm 40$ & $0.11573 \pm 43$ & $1892 \pm 7$ \\
\hline & 1500 & $82 / 82$ & $0.000025 \pm 13$ & $0.12096 \pm 42$ & $0.11877 \pm 28$ & $0.11842 \pm 20$ & $1933 \pm 3$ \\
\hline \multirow[t]{3}{*}{ LF-63A/5 } & $1450^{*}$ & $0 / 18$ & $0.000014 \pm 14$ & $0.07196 \pm 89$ & $0.11685 \pm 47$ & $0.11666 \pm 51$ & $1906 \pm 8$ \\
\hline & 1500 & $90 / 90$ & $0.000000 \pm 0$ & $0.10605 \pm 27$ & $0.11869 \pm 23$ & $0.11869 \pm 23$ & $1937 \pm 3$ \\
\hline & 1550 & $88 / 88$ & $0.000005 \pm 3$ & $0.14522 \pm 426$ & $0.11913 \pm 23$ & $0.11911 \pm 23$ & $1943 \pm 4$ \\
\hline \multirow[t]{3}{*}{ LF-63A/6 } & 1450 & $18 / 18$ & $0.000013 \pm 8$ & $0.10579 \pm 60$ & $0.11799 \pm 42$ & $0.11781 \pm 44$ & $1924 \pm 7$ \\
\hline & 1450 & $48 / 48$ & $0.000010 \pm 1$ & $0.10375 \pm 38$ & $0.11820 \pm 44$ & $0.11806 \pm 44$ & $1927 \pm 7$ \\
\hline & 1500 & $86 / 86$ & $0.000009 \pm 3$ & $0.15416 \pm 72$ & $0.11886 \pm 21$ & $0.11877 \pm 24$ & $1938 \pm 4$ \\
\hline LF-63A/7 & 1500 & $18 / 18$ & $0.000000 \pm 0$ & $0.14919 \pm 149$ & $0.11851 \pm 76$ & $0.11850 \pm 76$ & $1934 \pm 11$ \\
\hline \multirow{4}{*}{$\mathrm{LF}-63 \mathrm{~A} / 8$} & $1450^{*}$ & $0 / 70$ & $0.000035 \pm 10$ & $0.23962 \pm 1564$ & $0.11672 \pm 42$ & $0.11627 \pm 32$ & $1900 \pm 5$ \\
\hline & 1500 & $80 / 80$ & $0.000006 \pm 6$ & $0.33296 \pm 143$ & $0.11827 \pm 21$ & $0.11820 \pm 20$ & $1929 \pm 3$ \\
\hline & 1500 & $88 / 88$ & $0.000003 \pm 1$ & $0.33022 \pm 74$ & $0.11836 \pm 17$ & $0.11831 \pm 17$ & $1931 \pm 3$ \\
\hline & Total: & $820 / 1242$ & & & & Average age: & $1934 \pm 3$ \\
\hline \multirow[t]{3}{*}{ LF-58D/1 } & $1450^{*}$ & $0 / 18$ & $0.000022 \pm 4$ & $0.17349 \pm 104$ & $0.11838 \pm 44$ & $0.11809 \pm 44$ & $1928 \pm 7$ \\
\hline & 1500 & $86 / 86$ & $0.000030 \pm 7$ & $0.18449 \pm 45$ & $0.11894 \pm 17$ & $0.11855 \pm 19$ & $1935 \pm 3$ \\
\hline & 1550 & $84 / 84$ & $0.000018 \pm 3$ & $0.17534 \pm 40$ & $0.11880 \pm 17$ & $0.11856 \pm 17$ & $1935 \pm 3$ \\
\hline LF-58D/2 & 1500 & $18 / 18$ & $0.000017 \pm 4$ & $0.20512 \pm 105$ & $0.11864 \pm 33$ & $0.11841 \pm 33$ & $1933 \pm 5$ \\
\hline LF-58D/3 & 1500 & $18 / 18$ & $0.000000 \pm 0$ & $0.14999 \pm 175$ & $0.11826 \pm 71$ & $0.11826 \pm 71$ & $1930 \pm 11$ \\
\hline \multirow[t]{3}{*}{ LF-58D $/ 4$} & 1450 & $88 / 88$ & $0.000020 \pm 3$ & $0.15047 \pm 352$ & $0.11869 \pm 16$ & $0.11844 \pm 16$ & $1933 \pm 2$ \\
\hline & 1500 & $86 / 86$ & $0.000005 \pm 4$ & $0.17695 \pm 51$ & $0.11848 \pm 18$ & $0.11847 \pm 17$ & $1933 \pm 3$ \\
\hline & $1550^{*}$ & $0 / 36$ & $0.000055 \pm 56$ & $0.18542 \pm 133$ & $0.11872 \pm 63$ & $0.11798 \pm 98$ & $1926 \pm 15$ \\
\hline \multirow[t]{3}{*}{ LF-58D/5 } & 1450 & $50 / 50$ & $0.000043 \pm 4$ & $0.17875 \pm 56$ & $0.11924 \pm 23$ & $0.11867 \pm 27$ & $1936 \pm 4$ \\
\hline & 1500 & $88 / 88$ & $0.000026 \pm 2$ & $0.19296 \pm 44$ & $0.11895 \pm 25$ & $0.11859 \pm 24$ & $1935 \pm 4$ \\
\hline & Total: & $518 / 572$ & & & & Average age: & $1934 \pm 1$ \\
\hline LF-65A/2 & 1500 & $82 / 82$ & $0.000000 \pm 0$ & $0.14100 \pm 54$ & $0.11932 \pm 50$ & $0.11932 \pm 50$ & $1946 \pm 7$ \\
\hline LF-65A/3 & $1450^{*}$ & $0 / 18$ & $0.000000 \pm 0$ & $0.06742 \pm 64$ & $0.11525 \pm 69$ & $0.11525 \pm 69$ & $1884 \pm 11$ \\
\hline & $1500^{*}$ & $0 / 84$ & $0.000002 \pm 2$ & $0.08938 \pm 24$ & $0.11683 \pm 24$ & $0.11681 \pm 23$ & $1908 \pm 4$ \\
\hline & 1550 & $90 / 90$ & $0.000004 \pm 3$ & $0.12230 \pm 30$ & $0.11834 \pm 19$ & $0.11832 \pm 19$ & $1931 \pm 3$ \\
\hline LF-65A/4 & 1450 & $34 / 34$ & $0.000000 \pm 0$ & $0.14110 \pm 66$ & $0.11899 \pm 41$ & $0.11899 \pm 41$ & $1942 \pm 6$ \\
\hline LF-65A/5 & $1450^{*}$ & $0 / 50$ & $0.000020 \pm 1$ & $0.11693 \pm 150$ & $0.11767 \pm 64$ & $0.11740 \pm 65$ & $1917 \pm 10$ \\
\hline & 1500 & $76 / 76$ & $0.000020 \pm 2$ & $0.13704 \pm 26$ & $0.11890 \pm 36$ & $0.11863 \pm 34$ & $1936 \pm 5$ \\
\hline LF-65A/6 & $1450^{*}$ & $0 / 88$ & $0.000016 \pm 4$ & $0.09771 \pm 137$ & $0.11792 \pm 20$ & $0.11777 \pm 20$ & $1923 \pm 3$ \\
\hline & 1500 & $90 / 90$ & $0.000053 \pm 9$ & $0.13387 \pm 36$ & $0.11947 \pm 16$ & $0.11877 \pm 17$ & $1938 \pm 3$ \\
\hline & Total: & $372 / 612$ & & & & Average age: & $1936 \pm 4$ \\
\hline NN-205/1 & $1450^{*}$ & $0 / 88$ & $0.000016 \pm 2$ & $0.06739 \pm 135$ & $0.11350 \pm 15$ & $0.11329 \pm 16$ & $1856 \pm 2$ \\
\hline & $1500^{*}$ & $0 / 88$ & $0.000017 \pm 2$ & $0.13607 \pm 161$ & $0.11813 \pm 27$ & $0.11790 \pm 28$ & $1928 \pm 4$ \\
\hline & 1550 & $88 / 88$ & $0.000026 \pm 9$ & $0.15834 \pm 50$ & $0.11953 \pm 16$ & $0.11904 \pm 23$ & $1942 \pm 4$ \\
\hline NN-205/2 & $1450^{*}$ & $0 / 18$ & $0.000013 \pm 2$ & $0.09834 \pm 58$ & $0.11827 \pm 30$ & $0.11810 \pm 30$ & $1930 \pm 5$ \\
\hline & $1450^{*}$ & $0 / 98$ & $0.000015 \pm 1$ & $0.09614 \pm 49$ & $0.11736 \pm 13$ & $0.11715 \pm 13$ & $1918 \pm 4$ \\
\hline & 1500 & $82 / 82$ & $0.000013 \pm 3$ & $0.11812 \pm 262$ & $0.11887 \pm 14$ & $0.11872 \pm 14$ & $1937 \pm 2$ \\
\hline NN-205/3 & $1500^{*}$ & $0 / 52$ & $0.000000 \pm 0$ & $0.06800 \pm 57$ & $0.11474 \pm 23$ & $0.11474 \pm 23$ & $1876 \pm 4$ \\
\hline NN-205/4 & $1450^{*}$ & $0 / 95$ & $0.000007 \pm 1$ & $0.10464 \pm 336$ & $0.11790 \pm 38$ & $0.11781 \pm 38$ & $1925 \pm 6$ \\
\hline & 1500 & $90 / 90$ & $0.000016 \pm 2$ & $0.15519 \pm 37$ & $0.11938 \pm 19$ & $0.11918 \pm 20$ & $1944 \pm 3$ \\
\hline NN-205/5 & $1450^{*}$ & $0 / 96$ & $0.000002 \pm 1$ & $0.04121 \pm 56$ & $0.10978 \pm 28$ & $0.10978 \pm 28$ & $1796 \pm 5$ \\
\hline & $1500^{*}$ & $0 / 82$ & $0.000002 \pm 1$ & $0.07319 \pm 65$ & $0.11382 \pm 27$ & $0.11382 \pm 27$ & $1862 \pm 4$ \\
\hline NN-205/6 & $1450^{*}$ & $0 / 34$ & $0.000000 \pm 0$ & $0.03537 \pm 20$ & $0.11049 \pm 29$ & $0.11049 \pm 29$ & $1808 \pm 5$ \\
\hline & $1500^{*}$ & $0 / 86$ & $0.000002 \pm 2$ & $0.05556 \pm 94$ & $0.11313 \pm 42$ & $0.11313 \pm 42$ & $1851 \pm 7$ \\
\hline NN-205/7 & $1450^{*}$ & $0 / 84$ & $0.000036 \pm 3$ & $0.10310 \pm 80$ & $0.11889 \pm 18$ & $0.11838 \pm 19$ & $1940 \pm 3$ \\
\hline & 1500 & $82 / 82$ & $0.000008 \pm 3$ & $0.13570 \pm 31$ & $0.11966 \pm 16$ & $0.11959 \pm 16$ & $1950 \pm 2$ \\
\hline NN-205/8 & $1450^{*}$ & $0 / 18$ & $0.000017 \pm 6$ & $0.13545 \pm 72$ & $0.11914 \pm 34$ & $0.11892 \pm 35$ & $1944 \pm 5$ \\
\hline & $1450^{*}$ & $0 / 67$ & $0.000007 \pm 1$ & $0.13255 \pm 24$ & $0.11880 \pm 11$ & $0.11871 \pm 11$ & $1939 \pm 2$ \\
\hline & 1500 & $86 / 86$ & $0.000010 \pm 2$ & $0.15794 \pm 130$ & $0.11917 \pm 19$ & $0.11903 \pm 20$ & $1942 \pm 3$ \\
\hline & Total: & $428 / 1334$ & & & & Average age: & $1943 \pm 5$ \\
\hline LF-53/01 & \#1450 & $0 / 4$ & $0.004436 \pm 32$ & $0.25046 \pm 498$ & $0.17576 \pm 120$ & $0.11611 \pm 137$ & $1897 \pm 21$ \\
\hline & 1480 & $18 / 18$ & $0.000022 \pm 6$ & $0.13156 \pm 73$ & $0.11872 \pm 38$ & $0.11842 \pm 39$ & $1933 \pm 6$ \\
\hline & 1510 & $86 / 86$ & $0.000017 \pm 4$ & $0.14975 \pm 131$ & $0.11878 \pm 17$ & $0.11852 \pm 17$ & $1934 \pm 3$ \\
\hline LF-53/02 & $\# 1460$ & $0 / 16$ & $0.010242 \pm 694$ & $0.45753 \pm 3488$ & $0.25042 \pm 3729$ & $0.11656 \pm 280$ & $1904 \pm 43$ \\
\hline & 1500 & $86 / 86$ & $0.000024 \pm 1$ & $0.13214 \pm 97$ & $0.11883 \pm 23$ & $0.11849 \pm 24$ & $1934 \pm 4$ \\
\hline & 1550 & $82 / 82$ & $0.000018 \pm 17$ & $0.14224 \pm 83$ & $0.11872 \pm 26$ & $0.11831 \pm 26$ & $1931 \pm 4$ \\
\hline LF-53/03 & 1500 & $34 / 34$ & $0.000009 \pm 5$ & $0.14156 \pm 50$ & $0.11815 \pm 16$ & $0.11809 \pm 16$ & $1928 \pm 2$ \\
\hline & 1550 & $86 / 86$ & $0.000015 \pm 11$ & $0.14633 \pm 44$ & $0.11864 \pm 26$ & $0.11855 \pm 22$ & $1935 \pm 3$ \\
\hline LF-53/05 & $\# 1450$ & $0 / 32$ & $0.001188 \pm 86$ & $0.15893 \pm 123$ & $0.13489 \pm 53$ & $0.11836 \pm 96$ & $1932 \pm 15$ \\
\hline & 1500 & $80 / 80$ & $0.000018 \pm 4$ & $0.14910 \pm 34$ & $0.11894 \pm 17$ & $0.11869 \pm 17$ & $1937 \pm 3$ \\
\hline & 1550 & $90 / 90$ & $0.000054 \pm 3$ & $0.14164 \pm 34$ & $0.11911 \pm 19$ & $0.11839 \pm 23$ & $1932 \pm 3$ \\
\hline LF-53/06 & 1450 & $38 / 38$ & $0.000055 \pm 5$ & $0.10272 \pm 32$ & $0.11884 \pm 21$ & $0.11809 \pm 28$ & $1928 \pm 4$ \\
\hline & 1500 & $90 / 90$ & $0.000013 \pm 2$ & $0.10792 \pm 31$ & $0.11889 \pm 16$ & $0.11871 \pm 17$ & $1937 \pm 3$ \\
\hline & 1550 & $88 / 88$ & $0.000040 \pm 3$ & $0.12358 \pm 30$ & $0.11895 \pm 17$ & $0.11841 \pm 18$ & $1933 \pm 3$ \\
\hline
\end{tabular}


Table 3 (continued)

\begin{tabular}{|c|c|c|c|c|c|c|c|}
\hline Zircon & Evaporation temperature $\left({ }^{\circ} \mathrm{C}\right)$ & Used/total ratio number & ${ }^{204} \mathrm{~Pb} /{ }^{206} \mathrm{~Pb} \pm 2 \sigma$ & ${ }^{208} \mathrm{~Pb} /{ }^{206} \mathrm{~Pb} \pm 2 \sigma$ & ${ }^{207} \mathrm{~Pb} /{ }^{206} \mathrm{~Pb} \pm 2 \sigma$ & $\left({ }^{207} \mathrm{~Pb} /{ }^{206} \mathrm{~Pb}\right)_{\mathrm{c}} \pm 2 \sigma$ & Age (Ma) $\pm 2 \sigma$ \\
\hline \multirow{5}{*}{ LF-53/07 } & 1590 & $90 / 90$ & $0.000023 \pm 8$ & $0.12507 \pm 74$ & $0.11900 \pm 26$ & $0.11862 \pm 27$ & $1936 \pm 4$ \\
\hline & 1450 & $86 / 86$ & $0.000146 \pm 3$ & $0.12467 \pm 39$ & $0.12028 \pm 15$ & $0.11833 \pm 16$ & $1931 \pm 2$ \\
\hline & 1500 & $86 / 86$ & $0.000003 \pm 2$ & $0.13563 \pm 72$ & $0.11860 \pm 34$ & $0.11856 \pm 32$ & $1935 \pm 5$ \\
\hline & 1550 & $36 / 36$ & $0.000007 \pm 6$ & $0.16934 \pm 68$ & $0.11850 \pm 32$ & $0.11847 \pm 32$ & $1933 \pm 5$ \\
\hline & Total: & $1076 / 1124$ & & & & Average age & $1933 \pm 2$ \\
\hline
\end{tabular}

above the alkali feldspar solvus (Vernon et al., 1983), and the presence of quartz grains internally divided into subgrains of rectangular shape (chessboard pattern) indicates that c-slip was active during the development of the subsolidus microfabric and confirms the mentioned temperatures of around $650-750{ }^{\circ} \mathrm{C}$ (Blumenfeld et al., 1986; Kruhl, 1996). The deformational features observed in the studied rocks are related to the syn-kinematic emplacement of the SPS and are consistent with the high temperatures prevailing during slow cooling of magmatic bodies.

\section{Chemistry}

Chemical aspects of the SPS rocks have been described by Fraga (2002). The rocks are subalkaline and dominantly metaluminous. In the R1R2 multicationic diagram, they plot preferentially in the monzogranite to leucogranodiorite fields. $\mathrm{SiO}_{2}$ content of 27 of 31 analyzed samples varies from 63 to 74 wt.\%. Different $\mathrm{SiO}_{2}$ variation intervals were characterized for distinct bodies. The rocks of the Serra da Prata, Igarapé Grande and Igarapé Roxinho intrusions exhibit similar geochemical characteristics for most of the majorand trace-elements with slight differences in the $\mathrm{FeO}^{*} /\left(\mathrm{FeO}^{*}+\mathrm{M}-\right.$ gO) ratios. Compared to the charnockitic igneous rocks which represent the C-type granitoids described by Kilpatrick and Ellis (1992) and Nironen et al. (2000), the SPS rocks display similar variation trends for most major- and trace-elements.

\section{New $\mathrm{Pb}-\mathrm{Pb}$ zircon evaporation data}

Five samples representative of different textural and/or compositional facies of the SPS were selected for age determination (Table 2 ). The analyses were performed at the Laboratory of Isotope Geology of the Federal University of Pará - UFPA (Pará-Iso) using the $\mathrm{Pb}-\mathrm{Pb}$ method of single-zircon evaporation (Kober, 1986).

Zircon crystals were concentrated using standard methods and were then hand-picked from the least magnetic population. The isotopic compositions were determined on a FINNIGAN MAT 262 mass spectrometer, and the statistical treatment and age calculation procedures of Gaudette et al. (1998) were followed. Crystals or evaporation steps with lower ages which could reflect lead loss after crystallization, as well as those showing higher ages and considered as inherited, were rejected and not included in the calculation of mean age (Appendix). $\mathrm{Pb}-\mathrm{Pb}$ ages versus evaporation step diagrams for the analyzed samples are illustrated in Figure 5 and the analytical results are shown in Table 3.

Sample LF-63a represents a hypersthene-quartz syenite with hypidiomorphic inequigranular texture from the Serra da Prata intrusion. The zircon crystals are limpid, euhedral, prismatic grains with $\mathrm{L}: \mathrm{W}$ ratios of $1: 2-1: 3$, few inclusions and fractures, and display light yellow colour. Seven crystals were analyzed and six of them were used to calculate the mean age of $1934 \pm 3$ Ma.

The foliated porphyritic clinopyroxene charnockites of samples LF-58d and LF-65a (Serra da Prata intrusion) yielded prismatic, euhedral, limpid zircon crystals with few inclusions and fractures and light yellow or light pink colours (a colourless population occurs in sample LF-65a). The L:W ratio approximates to $1: 3$ in sam- ple LF-65a and varies from 1:1.5 to $1: 4$ in sample LF 58d. Five zircon crystals from sample LF-58d and six from sample LF-65a were analyzed and yielded mean ages of $1934 \pm 1 \mathrm{Ma}$ and $1936 \pm 4$ Ma, respectively.

Sample NN-205 is a highly deformed biotite-hornblende-bearing charnockite from the Serra da Prata intrusion. Zircon crystals show both limpid portions and zones with fractures and inclusions. They are euhedral to subhedral with $1: 2$ to $1: 3 \mathrm{~L}: \mathrm{W}$ ratios and light yellow colours. Eight grains were analyzed, including two crystal fragments, and yielded a mean age of $1943 \pm 5 \mathrm{Ma}$, the highest among the analyzed samples.

Sample LF-53 is a fine-grained quartz jotunite with well-preserved igneous (inequigranular) texture, interpreted as a syn-plutonic dyke from the Igarapé Grande intrusion. Seven limpid, prismatic, euhedral, light yellow- or light pink-coloured grains, including four crystal fragments, were analyzed. The calculated mean age corresponds to $1933 \pm 2 \mathrm{Ma}$.

The igneous origin of the zircon crystals, suggested by their morphology, has been confirmed by the behaviour of the isotopic $\mathrm{Pb}$ ratios. The ${ }^{208} \mathrm{~Pb} /{ }^{206} \mathrm{~Pb}$ ratios exhibit a pronounced variation relative to the ${ }^{207} \mathrm{~Pb} /{ }^{206} \mathrm{~Pb}$ ratios. According to Klötzli (1999), this kind of behaviour reflects the $\mathrm{U} / \mathrm{Th}$ ratio variation during magmatic growth. No traces of inherited Archean $\mathrm{Pb}$ component have been detected in the zircon crystals from the SPS.

\section{Discussion}

The geochronological analyses performed on the SPS samples (Table 1) were preceded by geological mapping accompanied by systematic structural, petrographic and geochemical studies. These studies took place not only in SPS but also in all associated units, including the Mesoproterozoic Mucajaí AMG Complex. The new understanding of the geological evolution of the area led to a better selection of samples for geochronological studies, resulting in a more consistent data set (Table 2) when compared with the previously reported ages (Table 1 ). The new $\mathrm{Pb}-\mathrm{Pb}$ zircon evaporation ages for the five analyzed samples are close and overlap within the analytical errors, constraining the age of the SPS in a time interval of ca. $10 \mathrm{Ma}$, between $1933 \pm 2 \mathrm{Ma}$ and $1943 \pm 5 \mathrm{Ma}$. Archean crustal inheritance has not been detected, suggesting the absence of Archean components in the magma source of the charnockitic rocks.

The Paleoproterozoic age characterized for the SPS contrasts with the Mesoproterozoic age of the mangerites of the Mucajaí AMG Complex (Table 2), indicating the existence of two different generations of charnockitic associations in the studied area.

The $1564 \pm 21 \mathrm{Ma} \mathrm{Pb}-\mathrm{Pb}$ zircon evaporation age reported by Fraga et al. (1999) for a quartz mangerite (sample NN-234, Fig. 2, Table 1), and envisaged at that time as the age of the Serra da Prata Suite, represents more probably a dyke, related to the Mesoproterozoic Mucajaí AMG Complex (Fig. 2), crosscutting the Paleoproterozoic Serra da Prata charnockitic rocks. Accordingly, the age of $1538 \pm 5 \mathrm{Ma}$ ( $\mathrm{Pb}-\mathrm{Pb}$ zircon evaporation, Fraga, 2002), obtained for the mangeritic facies of the Mucajaí Complex, is close to that reported for the quartz mangerite from sample NN-234. 
The $1827 \pm 19 \mathrm{Ma} \mathrm{U}-\mathrm{Pb}$ conventional age reported by Gaudette et al. (1996) for a charno-enderbite interpreted as a granulite of the Kanuku Complex was based on data points with a large spread. As mentioned by the authors, this age is difficult to interpret. It may represent a distinct charnockitic magmatism not related to the SPS, or to the Mucajaí Complex, but this is an isolated age that needs further confirmation. The $2019 \pm 71 \mathrm{Ma} \mathrm{Rb}-\mathrm{Sr}$ whole-rock errorchron age, interpreted as the age of the Kanuku high-grade metamorphism (Gaudette et al., 1996), was calculated using samples of different petrological origin and is apparently meaningless.

Despite the chemical differences in relation to the SPS rocks, the $1966 \pm 37 \mathrm{~Pb}-\mathrm{Pb}$ single-zircon evaporation age reported from a quartz jotunitic gneiss related to the Rio Urubu Suite (Fraga et al., 1997a) overlaps, within analytical errors, the $\mathrm{Pb}-\mathrm{Pb}$ ages obtained in the present study. The $1938 \pm 12 \mathrm{Ma}$ age (U-Pb zircon, SHRIMP, Santos, 2003, Table 2) obtained for the granulitic Barauana Gneiss is similar to that obtained for the SPS. The reported age could possibly reflect metamorphism. However, additional geological mapping, supported by geochronological studies, is needed for a better definition of the metamorphic evolution of the area.

The $\mathrm{Pb}-\mathrm{Pb}$ data obtained for the SPS, along with the new ages now available for the A-type Igarapé Branco and Igarapé Miracelha Granites (Fraga, 2002) reinforce the importance of the 1943-1933 Ga magmatic event in the central portion of the Guyana Shield. Moreover, most of the ages reported for the I-type calc-alkaline rocks of the Rio Urubu Suite are close to or concentrate in this time interval (Gaudette et al. 1996; Santos, 2003). It is worth noting that this is the only significant magmatic event within the 1943-1933 Ga interval identified in the Amazonian craton so far. The A-type and charnockitic magmatisms in the studied area were interpreted as the result of partial melting of the lower crust triggered by mafic underplating (Fraga, 2002) in consonance with what has been proposed by other authors (Kilpatrick and Ellis, 1992; Rämö and Haapala, 1995; Dall'Agnol et al., 2005). Accordingly, the reported Sm-Nd data suggest dominantly late-Rhyacian juvenile Transamazonian crustal sources for the SPS magma (Fraga, 2002). Considering the hypothesis that the age obtained for the Barauana gneiss refers to metamorphism, the mafic underplating could possibly also provide a heat source for the high-grade metamorphism of rock units slightly older than the SPS.

Concerning the tectonic setting of the charnockitic magmatism, two hypotheses can be envisaged. The SPS could be related to a post-collisional setting after the collage of the $2.03 \mathrm{Ga}$ arc complexes (Anauá and Trairão complexes) and Rhyacian continental masses, with the development of the Caurane-Coeroeni Belt. Alternatively, a post-collisional (or intracontinental ?) evolution related to the development of orogenic belts along the plate margins around 1.95-1.93 Ga could be envisaged for the charnockitic magmatism represented by the SPS. However, in the Guyana Shield, orogenic activities have not yet been characterized in this time interval.

\section{Conclusions}

The Serra da Prata Suite represents an important charnockitic magmatic event in the central part of the Guyana Shield. The Pb$\mathrm{Pb}$ ages obtained using the methodology of single-zircon evaporation have yielded a geologically coherent data set, constraining the age of the charnockitic magmatism to the interval of ca. $10 \mathrm{Ma}$, between $1933 \pm 2 \mathrm{Ma}$ and $1943 \pm 5 \mathrm{Ma}$. Within this time interval, Itype calc-alkaline granitoids as well as A-type granites were emplaced in the central part of the Guyana Shield confirming the importance of the 1.94-1.93 Ga magmatic event.
This 1.94-1.93 Ga magmatic event has not been identified outside this portion of the Amazonian craton and may be related to a post-collisional setting after the evolution of the Cauarane-Coeroeni Belt $(\sim 2.00 \mathrm{Ga})$, or alternatively, the event may represent post-collisional (or intracontinental?) magmatism related to orogenic activities along the plate margins around 1.95-1.94 Ga.

\section{Acknowledgements}

This paper presents part of the results of the Doctoral thesis of the first author, developed at The Universidade Federal do Pará (UFPA) under the supervision of João Batista Sena Costa. The CPRM-Geological Survey of Brazil financed the research, with partial support from FINEP. Laura Maria Rigoni Dias from Geological Survey of Brazil (DIEDIG) kindly drafted the figures. S. Martini and Ana Maria Dreher are thanked for their helpful comments. The authors also acknowledge J.S.F. Barbosa and anonymous reviewers for their expert and constructive reviews, which substantially improved this article. This paper is a contribution to the Pronex Project (MCT-CNPq, 66.2103/1998-0).

\section{Appendix Analytical. procedures}

The isotope analyses were carried out on a Finnigan MAT 262 mass spectrometer at the Isotope Geology Laboratory of the Federal University of Pará (Pará-Iso) by the zircon Pb-evaporation technique established by Kober $(1986,1987)$. The zircon crystals were concentrated and hand-picked by conventional methods of heavy mineral separation. A zircon grain was embedded into the evaporation filament, which was placed in front of the ionization filament, and both of them were introduced into the mass spectrometer. The evaporation filament was heated to evaporate the $\mathrm{Pb}$ from the zircon which precipitated on the cold ionization filament. Three evaporation steps of a maximum of five minutes each were performed at 1450,1500 and $1550{ }^{\circ} \mathrm{C}$. After each evaporation step, the temperature of the ionization filament was raised to $\mathrm{Pb}$ emission and the isotopic measurements were dynamically made with the ion counter of the instrument. Intensities of each $\mathrm{Pb}$ isotope were measured in one cycle by peak hopping in the 206207-208-206-207-204 mass sequence along five mass scans, defining one block of data with nine ${ }^{207} \mathrm{~Pb} /{ }^{206} \mathrm{~Pb}$ ratios. Five blocks were usually recorded for each evaporation step. The weighted ${ }^{207} \mathrm{~Pb} /{ }^{206} \mathrm{~Pb}$ mean for each block was corrected for common Pb utilizing the model of Stacey and Kramers (1975) and used for age calculation. Blocks yielding a ${ }^{204} \mathrm{~Pb} /{ }^{206} \mathrm{~Pb}$ mean above 0.0004 and those that scatter more than two standard deviations from the average age value were eliminated. The calculated age for one zircon grain was the weighted mean and standard error of the accepted blocks of data. The same procedure was adopted to calculate the age for a rock sample from a set of grains. The ages were presented with $2 \sigma$ error.

\section{References}

Almeida, F.F.M., de Hasui, Y., 1984. Introdução. In: ALMEIDA, F.F.M., de Hasui, Y. (Eds.), O Pré-Cambriano do Brasil. São Paulo, Edgar Blücher, 378p.

Almeida, E.M., Macambira, M.J.B., Oliveira, E.C., 2007. Geochemistry and zircon geochronology of I-type high-K calc-alkaline and S-type granitoid rocks from south-eastern Roraima, Brazil: Orosirian collisional magmatism evidence $(1.97-1.96 \mathrm{Ga})$ in central portion of Guyana Shield. Precambrian Research $155,69-97$.

Barron, C.N., 1966. Notes on the stratigraphy of central British Guyana. In: Conferência Geológica das Guianas, 4. Belém. Anais. Departamento de Nacional de Produção Mineral, Divisão de Geologia e Mineralogia, Avulso No. 41, pp. 121-126.

Berrangé, J.P., 1977. The geology of southern Guyana, South America. Overseas Memoir 4. Institute of Geological Sciences, London. p. 12.

Blumenfeld, P., Mainprice, D., Bouchez, J.L., 1986. C-Slip in quartz from subsolidus deformed granite. Tectonophysics 127, 97-115. 
Cole, E., Heesterman, L.J., 2002. Geological map of Guyana. Scale 1:1000.000. Georgetown. Guyana Geology and Mines Comission, Guyana.

Costa, J.B.S., Pinheiro, R.V.L., Reis, N.J., Pessoa, M.R., Pinheiro, S. da S., 1991. O Hemigraben do Tacutu, uma estrutura controlada pela geometria do Cinturão de Cisalhamento Guiana Central. Geociências, São Paulo, vol. 10, pp. 119-130 (abstract in English)

Dall'agnol, R., Teixeira, N.P.R., Rämö, O.T., Moura, C.A.V., Macambira, M.J.B., Oliveira, D.C., 2005. Petrogenesis of the Paleoproterozoic rapakivi, A-type granites of the Archean Carajás Metallogenic Province. Lithos 80, 101-129.

De Vleter, D.R., Aleva, G.J.J., Kroonenberg, S.B., 1998. Research into Precambrian of Surinam. In: Wong, Th.E., De Vleter, D.R., Krook, L., Zonneveld, J.I.S., Van Loon, A.J. (Eds.), The History of Earth Sciences in Surinam - Kon. Ned. Akad. Wet. and Ned. Inst. Toegep. Geowet. TNO, pp. 15-64.

Delor, C., Lahondère, D., Egal., E., Lafon, J.M., Cocherie, A., Guerrot, C., Rossi, P. Truffert, C., Theveniaut, H., Philips, D., Avelar, V.G. de, 2003a. Transamazonian crustal growth and reworking as revealed by the 1:500.000-scale geologica map of French Guyana, In: Geologie de la France, vols. 2-4, pp. 5-57.

Delor, C., Roever, E.W.F. de, Lafon, J.M., Lahondère, D., Rossi, P., Cocherie, A., Guerrot, C., Potrel, A., 2003b. The Bakhuis ultrahigh-temperature granulite bel Surinam): II Implications for late Transamazonian crustal stretching in revisited Guiana Shield framework. In: Geologie de la France, second ed., vols. $2-4$, pp. $207-230$

Faria, M.S.G. de, Luzardo, R., Reis, N.J., 2000. Complexo Metamórfico Anauá. In: CPRM, Programa Levantamentos Geológicos Básicos - PLGB. Caracaraí, Folhas NA.20-Z-B e NA.20-Z-D (integrais) e NA.20-Z-A, NA.21-Y-A, NA.20-Z-C e NA.21 Y-C (parcias). Escala 1:500.000. Estado de Roraima. CPRM, Brasília/SUREG-MA pp. 12-22 [CD-ROM] (abstract in English)

Faria, M.S.G. de, Santos, J.O.S., Luzardo, R., Hartmann, L.A., 2002. The oldest arc of the Roraima State, Brazil - $2.03 \mathrm{Ga}$ : zircon SHRIMP U-P geochronology of Anaua Complex. In: Congresso Brasileiro de Geologia, 41. João Pessoa. Anais. Sociedade Brasileira de Geologia, vol. 1, p. 306.

Fraga, L.M., 2002. A Associação Anortosito-Mangerito Granito Rapakivi (AMG) do Cinturão Guiana Central e suas encaixantes paleoproterozóicas: Evolução Estrutural, Geocronologia e Petrologia. Doctoral Thesis, Universidade Federa do Pará, Belém, 351p. (abstract in English).

Fraga, L.M.B., Araújo, R.V. de, 1999. Suíte Intrusiva Serra da Prata. In: CPRM Programa Levantamentos Geológicos Básicos - PLGB. Roraima Central, Folhas NA.20-X e NA.21-V, Estado de Roraima, escala 1:500.000. CPRM, Brasília/ SUREG-MA, pp. 83-89 [CD-ROM] (abstract in English).

Fraga, L.M., Costa, J.B.S., 2003. High temperature fabrics related to the synkinematic emplacemente of the Igarapé Branco A-Type Gneiss, Central Guyana Belt, North Amazonian craton, Brazil. In: Simposio Nacional de Estudo Tectônicos, 9. Búzios, Brazil. Expanded abstracts. Sociedade Brasileira de Geologia, pp. 169-172.

Fraga, L.M.B., Almeida, M.E., Macambira, M.J.B., 1997a. First lead-lead zircon ages of charnockitic rocks from Central Guiana Belt (CGB) in the state of Roraima, Brazil. In: South-American Symposium on Isotope Geology. Campos do Jordão Brazil, Extended abstracts, pp. 115-117.

Fraga, L.M.B., Araújo, R.V. de, Duarte, B.P., 1997b. Igneous charnockitic rocks of the Kanuku Complex and Serra da Prata Suite in the Central Guiana Belt (CGB) Roraima State, Brazil. In: International Symposium on Granites and Associated Rocks (ISGAM), 2. Salvador, Brazil. Extended abstracts, Sociedade Brasileira de Geologia, pp.112-113.

Fraga, L.M.B., Haddad, R.C., Reis, N.J., 1997c. Aspectos geoquímicos dos granitóides da Suíte Intrusiva Pedra Pintada, norte do Estado de Roraima. Revista Brasileira de Geociências, 27, 3-12. (abstract in English).

Fraga, L.M.B., Reis, N.J., Costa, J.B.S., 1998. O Cinturão Guiana Central no Estado de Roraima. In: Congresso Brasileiro de Geologia, 40. Belo Horizonte. Anais. Sociedade Brasileira de Geologia, p. 411.

Fraga, L.M.B., Araújo, R.V. de, Haddad, R.C., 1999. Suíte Metamórfica Rio Urubu. In: CPRM, Programa Levantamentos Geológicos Básicos - PLGB. Roraima Central, Folhas NA.20-X e NA.21-V, Estado de Roraima, escala 1:500.000. CPRM, Brasília/ SUREG-MA, pp. 38-48. [CD-ROM] (abstract in English)

Fraga, L.M, Dall'Agnol, R. Macambira, M.J.B., 2003. The Mucajaí AnorthositeMangerite-Rapakivi Granite (AMG) Complex, North Amazonian craton, Brazil. Geophysical Researches Abstracts 5, 14489. (European Geophysical Society) [CD-ROM].

Fraga, L.M., Dall'Agnol, R., Macambira, J.B., 2004. A- and C-type gneisses of the Central Guyana Belt, North Amazonian craton. In: International Geological Congress, 32. Florence, Italy. Abstract, [CD-ROM].

Fraga, L.M., Dall'Agnol, R., Costa, J.B.S., Macambira, M.J.B., 2006. Two distinct synkinematically emplaced A-type granites in the Guyana Shield, northern Amazonian craton. In: Dall'Agnol, R. Rosa-Costa, L.T. Klein, E.L. (Eds.) Symposium on Magmatism, Crustal Evolution and Metallogenesis of the Amazonian craton. Abstract Volume and Field Trips Guide. Belém, PRONEXUFPA-NO, 150p.

Fraga, L.M., Reis, N.J. Dall'Agnol, R, Armstrong, R, 2008a. Cauarane - Coeroeni Belt - The tectonic southern limit of the preserved Rhyacian crustal domain in the Guyana Shield, northern Amazonian craton. In: International Geological Congress, 33. Oslo, Norway. Abstract, [CD-ROM]

Fraga, L.M.B., Dreher, A. M., Grazziotin, H., 2008b. Nota Explicativa do Mapa Geológico da Folha Vila de Tepequém - Projeto Amajari. CPRM, ERJ, Internal Report.

Fraga, L.M., Dreher, A.M., Lafon, J.-M., 2008c. Orosirian, A- and I-type acid volcanism in the Guyana Shield, northern Amazonian craton. In: International Geological Congress, 33, Oslo, Norway. Abstract, [CD-ROM].
Gaudette, H.E., Olszewski, W.J., 1985. Geochronology of the basementrocks, Amazonas Territory, Venezuela, and the tectonic evolution of the western Guiana Shield. Geol. Mijnbouw. 64, 131-143.

Gaudette, H.E., Olszewski, W.J., Santos, J.O.S. dos, 1996. Geochronology of Precambrian rocks from the northern part of Guiana Shield, state of Roraima, Brazil. Journal of South American Earth Sciences 9, 183-195.

Gaudette, H.E., Lafon, J.-M., Macambira, M.J.B, Moura, C.A.V., Scheller, T., 1998 Comparison of single filament $\mathrm{Pb}$ evaporation/ionization zircon ages with conventional $\mathrm{U}-\mathrm{Pb}$ results: examples from the Precambrian of Brazil. Journal of South American Earth Sciences 11, 351-363.

Gibbs, A.K., Barron, C.N., 1993. The Geology of the Guiana Shield. Oxford University Press, New York, Claredon Press, 245p.

Kilpatrick, J.A., Ellis, D.J., 1992. C-type magmas, igneous charnockites and their extrusive equivalents. Transactions of the Royal Society of Edinburgh: Earth Sciences 83, 155-164.

Klötzli, U.S., 1999. Th/U zonation in zircon derived from evaporation analysis: model and its implications. Chemical Geology 158, 325-333.

Kober, B., 1986. Whole grain evaporation for ${ }^{207} \mathrm{~Pb} /{ }^{206} \mathrm{~Pb}$ age investigations on single zircons using double filament source. Contributions to Mineralogy and Petrology 93, 482-490.

Kober, B., 1987. Single-zircon evaporation combined with $\mathrm{Pb}^{+}$emitter bedding for ${ }^{207} \mathrm{~Pb} /{ }^{206} \mathrm{~Pb}$-age investigations using thermal ion mass spectrometry, and implications to zirconology. Contributions to Mineralogy and Petrology 96 63-71.

Kroonemberg, S.B., 1976. Amphibolite-facies and granulite-facies metamorphism in the Coeroeni-Lucie area, southwestern Surinam. Ph.D. Thesis, Amsterdan, Geologie en Mijnbouw, Dienst sur. Med., 25, 109-289.

Kruhl, J.H., 1996. Prism- and basal plane parallel subgrain boundaries in quartz: a microstructural geothermobarometer. Journal of Metamorphic Geology 14, 581-589.

Lima, M.I.C. de, Oliveira, E.P. de, Tassinari, C.C.G., 1982. Cinturões granulíticos da porção setentrional do Cráton Amazônico. In: Simpósio de Geologia da Amazônia, 1. Belém. Anais. Sociedade Brasileira de Geologia, vol. I, pp. 147-162.

Nironen, M., Elliot, B.A., Rämö, D.T.,2000.1.88-1.87 Ga post-kinematic intrusions of the Central Finland Granitoid Complex: a shift from C-type to A-type magmatism during lithospheric convergence. Lithos 53, 37-58.

Passchier, C.W., Trouw, R.A.J., 1996. Micro-Tectonics. Springer-Verlag, Berlin. 289p.

Rämö, O.T., Haapala, I., 1995. One hundred years of Rapakivi Granite. Contributions to Mineralogy and Petrology 52, 129-185.

Reis, N.J., Fraga, L.M.B., Faria, M.S.G. de, Almeida, M.E., 2003. Geologia do Estado de Roraima, Brasil. In: Geologie de la France, vols. 2-4, pp. 121-134.

Roever, E.W.F. de, Lafon, J.M., Delor, C., Cocherie, A., Rossi, P., Guerrot, C., Potrel, A., 2003. The Bakhuis ultrahigh-temperature granulite belt (Surinam): I Petrological and geochronological evidence for a counterclockwise P-T path at 2.07-2.05 Ga. In: Geologie de la France, vols. 2-4, pp. 175-205

Rosa-Costa, L.T., Lafon, J-M, Delor, C., 2006. Zircon geochronology and Sm-Nd isotopic study: further constrains for the Archean and Paleoproterozoic geodynamic evolution of the southeastern Guiana Shield, north Brazil. Gondwana Research 10, 277-300.

Santos, J.O.S. dos, 2003. Geotectônica dos escudos das Guianas e Brasil-Central. In Bizzi, L.A., Schobbenhaus, C., Vidotti, R.M., Gonçalves, E.J.H. (Eds.), Tectônica e Recursos Minerais do Brasil. CPRM, Brasília.

Santos, J.O.S. dos, Olszewski, W.J., 1988. Idade dos granulitos tipo Kanuku em Roraima. In: Congresso Latinoamericano de Geologia 7. Belém. Anais. Sociedade Brasileira de Geologia/Departamento de Nacional de Produção Mineral, pp. 378-388.

Santos, J.O.S. dos, Hartman, L.A., Gaudette, H.E., Groves, D.I., Mcnaugthon, N.J., Fletcher, I.R, 2000. A new understanding of the Provinces of the Amazon Craton based on integration of field mapping and $\mathrm{U}-\mathrm{Pb}$ and $\mathrm{Sm}-\mathrm{Nd}$ geochronology. Gondwana Research 3, 453-488.

Santos, J.O.S. dos, Potter, P.E., Reis, N.J., Hartmann, L.A., Fletcher, I.R., Mcnaughton, N.J., 2003a. Age, source and regional stratigraphy of the Roraima Supergroup and Roraima-like Sequences in Northern South America, based on U-Pb geochronology. Geological Society of America Bulletin 115, 331-348.

Santos, J.O.S. dos, Reis, N.J., Chemale, F., Hartmann, L.A., Pinheiro, S.S., Mcnaughton, N.J., 2003b. Paleoproterozoic evolution of the North-western Roraima State absence of Archean crust, based on $\mathrm{U}-\mathrm{Pb}$ and $\mathrm{Sm}-\mathrm{Nd}$ isotopic evidence. In: South-American Symposium on Isotope Geology, vol. 4, Salvador, Brazil, pp. 278-281 (Short papers)

Santos, J.O.S. dos, Hartmann, L.A., Faria, M.S.G., de, Riker, S.R.L., Souza, M.M. de, Almeida, M.E., 2006. A Compartimentação do Craton Amazonas em Províncias: Avanços ocorridos no período 2002-2006. In: Simpósio de Geologia da Amazônia, vol. 9, Belém, Sociedade Brasileira de Geologia. [CD-ROM].

Schobbenhaus, C., Hoppe, A., Lork, A., Baumann, A., 1994. Idade U/Pb do magmatismo Uatumã no norte do Cráton Amazônico, Escudo das Guianas (Brasil): Primeiros resultados. In: Congresso Brasileiro de Geologia 38, Camboriú. Anais. Sociedade Brasileira de Geologia, vol. 2, pp. 395-397.

Schobbenhaus, C., Gonçalves, J.H., Santos, J.O., Abram, M.B., Leão Neto, R., Matos, G.M.M., Vidotti, R.M., Ramos, E., M.A.B., Jesus, J.D.A. de (Eds.), 2004. Carta do Brasil ao milionésimo, Sistema de Informações Geográficas-SIG, Programa Geologia do Brasil, CPRM, Brasília [CD-ROM].

Spooner, C.H., Berrangé, J.P., Fairbairn, H.W., 1971. Rb-Sr whole-rock age of the Kanuku complex, Guyana. Geological Society of America Bulletin 82, 207-210.

Stacey, J.S., Kramers, J.D., 1975. Approximation of terrestrial Pb isotope by a two stage model. Earth and Planetary Science Letters 36, 207-221. 
Tapias, J.G., Guevara, A.N., Mejía, D.M.J., Ramiréz, N.E.M., Ospina, J.S., Naranjo, J.A.O., Avella, M.L.T., Penagos, M.M., Narváez, T.G., Diederix, H., Penã, H.U., 2006. Mapa Geológico De Colombia. Primera Edición., Ingeominas, Servicio Geológico, Instituto Colombiano De Geología Y Minería, Ministerio De Minas Y Energia.

Tassinari, C.C.G., Macambira, M.J.B., 2004. A evolução tectônica do Cráton Amazônico. In: Mantesso Neto, V., Bartorelli, A., Carneiro, C.D.R., Neves, B.B.B. (orgs.). Geologia do continente Sul-americano: evolução da obra de Fernando Flávio Marques de Almeida. S. Paulo, BECA, pp. 471-485.

Tassinari, C.G., Munhá, J.M.U., Teixeira, W., Palácios, T., Nutman, A.P., Sosa, C., Santos, A.P., Calado, B.O., 2004. The Imataca Complex, NW Amazonian craton, Venezuela: crustal evolution and integration of geochronological and petrological cooling histories. Episodes 27, 3-12.
Vanderhaege, O., Ledru, P., Thiéblemont, D., Egal., E., Cocherie, A., Tegyey, M., Milési, J., 1998. Contrasting mechanism of crustal growth geodynamic evolution of the Paleoproterozoic granite-greenstone belts of French Guiana. Precambrian Research, 92, 165-193.

Vernon, R.H., Williams, V.A., Dárcy, W.F., 1983. Grain-size reduction and foliation development in deformed granites. Tectonophysics 92, 123-145.

Wynn, J.C., Cox, D.P., Gray, F., Schruben, P.G., 1983. Geologic and Tectonic Map of the Venezuelan Guayana. In: US Geological Survey Bulletin 2062, Plate 2.

Yund, A., Tullis, J., 1991. Compositional changes of minerals associated with dynamic recrystallization. Contributions to Mineralogy and Petrology 108, 346355. 